DOI: http://dx.doi.org/10.18524/2307-4663.2020.2(49).204270

УДК $578.81+57.083 .33$

\author{
Л.О. Максименко \\ Інститут мікробіології і вірусології ім. Д.К.Заболотного НАН України, \\ вул. Академіка Заболотного, 154, Київ, 03143, Україна, \\ тел.:+38(044)526 94 24, e-mail: maksymenko.1.a@gmail.com

МОРФОЛОГО-СТРУКТУРНІ, КІЛЕРНІ
ТА СЕРОЛОГІЧНІ ВЛАСТИВОСТІ
МАКРОМОЛЕКУЛЯРНИХ БАКТЕРІОЦИНІВ
РЕСТОВАСТЕRIUМ САRОТОVОRUM SUBSP.
САRОТОVОRUМ ТА ЇХ СПОРДНЕНІСТЬ
З БАКТЕРІОФАГОМ ZF40

Мета. Визначення спорідненості між білковими компонентами макромолекулярних бактеріоцинів (MCTV), виділених з різних природних ізолятів Pectobacterium carotovorum subsp.carotovorum i бактерioфaza ZF40. Memoди. Бактеріоцини Р. саготоvотит отримували індукцією налідиксовою кислотою. Суміш каротоворицинів розділяли ультрацентрифугуванням. Електронномікроскопічні дослідження бактеріоцинів проводили за допомогою мікроскопа JEOL1400. Бактеріофаг ZF40 виділяли методом злитного лізису. Кілерну активність MCTV $і$ бактеріофага ZF40 визначали за допомогою популяиійних дисочіантів RC 5297 i RC 5195. Серологічну спорідненість білкових компонентів MCTV $і$ бактеріофага ZF40 визначали за допомогою отриманих до зазначених структур відповідних кролячих антисироваток. Результати. Фітопатогенні бактерї Р. carotovorum в результаті індукції налідиксовою кислотою, продукують множину макромолекулярних бактеріоцинів. Вони проявляють антимікробну дію відносно різних штамів бактерій P. carotovorum ma Esherichia coli. Електронномікроскопічні дослідження очищених фракиій MCTV з ізолятів Р. саготоvогит різних областей України(Б1-Б26) показали, щзо вони мають вигляд хвостових відростків бактеріофагів, а також сферичних часток різного діаметра. Білковий склад МСTV різних ізолятів P. саготоvотит може відрізнятися мінорними фракціями пептидів. За допомогою кролячої антисироватки, одержаної до МCTV J2 виявлені серологічно споріднені білки у складі бактеріофага ZF40. Методом імуноблотингу з використанням антисироватки, одержаної до структурних білків бактеріофага ZF40, виявлені серологічно споріднені білки у складі MCTV/J2 і бактеріофага ZF40 з молекулярною масою 72,66, 39 і 24 кД. Обробка сумімі MCTV кролячою антисироваткою до бактеріофагу ZF40, призводить до втрати їх кілерної активності. Висновки. МСТV, отримані з лізатів нових ізолятів бактерій Р. сагоtovorum, виділених в Україні, представляють собою велику множину, відрізняються за розміром і мають різні морфолого-структурні показники. Вони мають у своєму складі серологічно споріднені білки з білковими компонентами бактеріофага ZF40. Отримані факти підтверджують фагову природу макромолекулярних бактеріоцинів. Ключові слова: Pectobacterium carotovorum subs.carotovorum, макромолекулярні бактеріоцини, бактеріофаг ZF40,білки, серологічна спорідненість.

(C) Л.О. Максименко, 2020 
Актуальним завданням для сучасності є пошук нових природних антибіотичних речовин. Фітопатогенні бактерії Pectobacterium carotovorum subsp. carotovorum здатні продукувати частки з антибактеріальними властивостями. Під дією на бактеріальні клітини певних індукторів, наприклад, налідиксової кислоти, мітоміцину С, УФ-випромінювання та ін., бактерією продукуються дефектні частки - макромолекулярні бактеріоцини (MCTV) і низькомолекулярні каротоворицини (CTV) [5]. При цьому повноцінні бактеріофаги не утворюються. Наявність бактеріоцинів відображає дефектно-лізогенний стан цісї бактерії. Відомо, що клітини одного й того ж штаму бактерій можуть нести декілька різних типів фагових хвостових відростків і фагових головок [6]. Велика увага приділяється вивченню їх кілерної активності відносно родини Enterobacteriaceae, що в подальшому може дати змогу використання їх властивостей в народному господарстві. Утворення більшості високо- і низькомолекулярних кілерних часток регулюється SOS-системою клітини-хазяїна [6]. Раніше дослідження морфології часток MCTV показали, що їх структура подібна хвостовому відростку бактеріофагів родини Myoviridae [10]. Відомо, що макромолекулярні бактеріоцини починають реалізувати властиву їм кілерну активність завдяки прикріпленню до рецепторів на клітинній стінці бактерій і руйнуванню оболонки клітини. Бактеріофаги, на відміну від бактеріоцинів, вводять в клітину власну ДНК і відроджують свою популяцію. Вид помірно-го бактеріофага Pectobacterium carotovorum - ZF40 був вперше виділений і описаний Ф.І.Товкачем [7].

У бактеріофага ZF40 наряду з морфологічними властивостями, аналіз сиквенса генома показав, що він $є$ типовим представником бактеріофагів родини Myoviridae (морфотип А1) [7, 9]. В літературі є свідчення про спорідненість бактеріоцинів і бактеріофагів [13]. Так, методом імуноблоту показано, що за допомогою сироватки одержаної до білків бактеріофага PS17, виявляються фагові білки у складі піоцина R2 Pseudomonas aeruginosa [13]. В зв'язку з цим метою нашого дослідження було визначення спорід-неності між білковими компонентами макромолекулярних бактеріоцинів (MCTV), виділених з різних природних ізолятів Pectobacterium carotovorum subsp. carotovorum і бактеріофага ZF40.

\section{Матеріали і методи}

Для виділення і дослідження властивостей бактеріоцинів в даній роботі використовували ізоляти штамів пектолітичних фітопатогенних бактерій, наведених в таблиці.

Ізоляти фітопатогенних бактерій (Б1-Б26) з різних областей України були ідентифіковані нами як Pectobacterium carotovorum subsp.carotovorum. Вони мають подібні властивості з типовим штамом P. carotovorum $\mathrm{J} 2$ NCPPB 1744 [1]. Для вирощування бактерій використовували рідкі та агаризовані живильні середовища. Агаризовані живильні середовища містили 1,4\% агару. Як джерело вуглецю використовували глюкозу і пектин. Мінімальне рідке середовище (М 9) містило: $\mathrm{Na}_{2} \mathrm{HPO}_{4}-6$ г/л, $\mathrm{KH}_{2} \mathrm{PO}_{4}-3$ г/л, $\mathrm{NaCl}-$ 0,5 г/л, $\mathrm{NH}_{4} \mathrm{Cl}-1$ г/л. Після стерилізації на 1 л середовища додавали 1 мл $1 \mathrm{M}$ розчину $\mathrm{MgSO}_{4} \times 7 \mathrm{H}_{2} \mathrm{O}, 100$ мкл $10 \% \mathrm{CaCl}_{2}$ і глюкозу в кінцевій концентрації 
0,2\% . Підрощування бактерій і індукцію бактеріоцинів проводили як описано в $[5,6]$. Суміш бактеріоцинів розділяли центрифугуванням в центрифузі Beckman (США) при 30000 об./хв протягом 4-х годин в цукрозному градієнті (5-20\%), з вмістом 10-20\% етилового спирту. Осади макромолекулярних бактеріоцинів (MCTV) ресуспендували і діалізували в буфері М9 без глюкози.

Таблиця

Штами бактерій, використані в дослідженні

Table

Bacterial strains used in the research

\begin{tabular}{|c|c|c|c|}
\hline Бактерії & Номер штама & Рослина-хазяїн & Місце виділення \\
\hline \multirow{4}{*}{$\begin{array}{l}\text { Pectobacterium carotovorum } \\
\text { subsp. Carotovorum (Pcc) }\end{array}$} & \begin{tabular}{|l|} 
NCPPB 1744 \\
J2
\end{tabular} & $\begin{array}{l}\text { Daucus sativus } \\
\text { Roehl }\end{array}$ & Японія \\
\hline & Б1 & \begin{tabular}{|l}
$\begin{array}{l}\text { Solanum } \\
\text { tuberosum L. }\end{array}$ \\
\end{tabular} & $\begin{array}{l}\text { Україна, Черкаська } \\
\text { область }\end{array}$ \\
\hline & Б3, Б4, Б13, Б15 & $-“-$ & $\begin{array}{l}\text { Україна, Київська } \\
\text { область, Новосілки }\end{array}$ \\
\hline & $\begin{array}{l}\text { Б2, Б11, Б12, Б16, } \\
\text { Б17, Б23 }\end{array}$ & $-“-$ & $\begin{array}{l}\text { Україна, Київська } \\
\text { область, Васильків }\end{array}$ \\
\hline \multirow{3}{*}{$\begin{array}{l}\text { Pectobacterium carotovorum } \\
\text { subsp. carotovorum }(P c c)\end{array}$} & $\begin{array}{l}\text { Pcc } 62 \text { A } \\
\text { ATTCC } 15359\end{array}$ & Beta vulgaris L. & Білорусь \\
\hline & Pcc 2M & \begin{tabular}{|l} 
Solanum \\
tuberosum L.
\end{tabular} & Росія \\
\hline & $\begin{array}{l}\text { Pcc 153 ATCC } 15359 \\
(\text { NCPPB 1847) }\end{array}$ & Daucus sativus & США, Шотландія \\
\hline
\end{tabular}

Бактеріофаг ZF40 виділяли методом злитного лізису [4]. Кілерну активність бактеріофага ZF40 і MCTV визначали за допомогою популяційних дисоціантів Pcc RC 5297 i Pcc RC 5195. Дисоціант Pcc RC 5195 не здатен до адсорбції бактеріофага ZF40, тоді як бактерії Рcc RC 5297 адсорбують як бактеріоцини типу фагових хвостових відростків, так і бактеріофаг ZF40 [2].

Для визначення морфології бактеріоцинів очищені препарати наносили на сіточки з нітроцелюлозними підтримувальними плівками і контрастували $2 \%$ уранілацетатом. Електронномікроскопічні дослідження проводили за допомогою мікроскопа JEOL 1400 (Японія) при інструментальному збільшенні 20000-40000.

До бактеріофагу ZF-40 і MCTV/ J2 одержували кролячу антисироватку. Концентрацію білка бактеріоцинів визначали за оптичною густиною розчину при 278нм на Specord. Згідно Shepard и Socor (Phytopatology, 1969) 12,3 оптичні одиниці відповідають 1 мг/мл білка. До білкової суміші бактеріоцинів додавали рівний об’єм адьюванта Фрейнда і підшкірно імунізували кроля. Реімунізацію здійснювали через місяць. Білкову суміш вводили внутрішньовенно. Після реімунізації, через 7 днів, відбирали кров і одержували сироватку. Електрофоретичне розділення білків проводили за Laemmli [11]. Як маркери використовували стандартну суміш білків фірми Pharmacia (Швеція). Серологічну спорідненість білків бактеріофага ZF-40 і MCTV визначали за 
Ouchterlony O. [15]. Імуноблотинг білків - по методу Towbin [16]. Перенос білкових смуг з ПААГ здійснювали на нітроцелюлозний фільтр Schleicher $\&$ Schul з розміром пор 0,45 мкм. Вільні місця на нітроцелюлозі блокували $1 \%$ розчином БСА в 20мМ трис-НCl буфері, 20мМ трис-HCl, з вмістом 0,5 M $\mathrm{NaCl}$. Далі фільтри занурювали в розведену вищезазначеним буфером сироватку, одержану до бактеріофага ZF-40. Фільтри витримували з сироваткою протягом 10 год при кімнатній температурі й помірному помішуванні. Далі їх добре відмивали від сироватки й переносили в кон'югат „других” антитіл проти імуноглобулінів кроля, міченого фосфатазою „Sigma” NoA2556. Через 2 години фільтри добре промивали і переміщували їх у розчин бензидину в 20мМ трис- $\mathrm{HCl}$ буфері з вмістом $0,14 \mathrm{M} \mathrm{NaCl}$ і 0,03\% $\mathrm{H}_{2} \mathrm{O}_{2}$. Після потемніння смуг, імунохімічну реакцію зупиняли. Для цього фільтри переносили у дистильовану воду, добре промивали і висушували.

\section{Результати досліджень}

У складі природних штамів $P$. carotovorum, виділених в різних областях України виявлені бактеріоцини у вигляді хвостових відростків (MCTV), довжиною від 550 до 780нм (a); MCTV у вигляді хвостових відростків зі скороченими чохлами довжиною 120-170 нм (б), дрібні сферичні бактеріоцини, діаметром 15-20 нм, а також сферичні частки, які нагадують фагові головки різного діаметру (50-120 нм) (с, д) (Рис. 1).

На рис. 2 видно зони лізису, спричинених МСTV, виділених з різних ізолятів бактерій щодо чутливої культури P. carotovorum RC 5297.

Ізоляти штамів P. carotovorum містять бактеріоцини, які лізують клітини бактерій-індикаторів по різному. MCTV не можуть адсорбуватися на клітинах, $з$ яких вони були виділені. Також є відмінність між чутливістю бактерій, виділених з різних регіонів України до бактеріоцинів одне одного. Це може свідчити про те, що ізоляти бактерій відрізняються за набором MCTV, або на поверхні їх клітин відсутні відповідні рецептори.

Бактеріоцини ізолятів Б1-Б26 електрофоретично розділяються на 1215 білкових смуг [1]. Трьох мажорних білків з молекулярними масами 65 кД, 55 кД, 40 кД; 5 смуг проміжних білків 3 мол.масами 72 кД, 38 кД, 30 кД, 22 кД i 18 кД, а також 5 мінорних полосок : 86 кД, 76кД, 47кд, 46 кД и 45 кД. Згідно 3 даними літератури, MCTV штаму J2 мають білок 50 кД, якому відповідає покровний білок чохла скоротливого хвостового відростка; 19 кД - внутрішній білок стержня; 68 кД и 76кД - білки хвоста; 28кД, 36 кД і 42 кД - білки базальної пластинки і фібрил $[8,14]$.

MCTV ізолятів бактерій Б1-Б26 дещо відрізняються за набором проміжних і мінорних фракцій білків від колекційного штаму J2. Наші результати відносно вмісту мажорних білків бактеріоцинів штаму J2 достатньо близько співпадають 3 даними японських дослідників [14]. Можливо, що в штамах різного походження може відбуватися перерозподіл проміжних і мінорних фракцій білків MCTV в залежності від складу множини бактеріоцинів. У складі бактеріофага ZF40 визначені 13 структурних білків з молекулярними масами від 16 до 90 кД [ 4] 4 з них - мажорні, 3 - проміжні, решта - мінорні фракції. Попередньо нами [3] за допомогою антисироватки, одержаної до бак- 
теріоцинів типу фагових хвостових відростків, виділених з Рсc J2 (Японія), виявлені серологічно споріднені але неідентичні білки в каротоворицинах Pcc 2M (Росія), Рcc 62А (Білорусь) та Рcc 153 (США), а також було показано серологічну спорідненість білків бактеріоцинів з білками бактеріофага ZF-40.

В даній роботі за допомогою антисироватки, одержаної до бактеріофага ZF-40 у складі MCTV штамів Б1, Б2, Б16, Б23 виявлені серологічно споріднені та ідентичні білки з білками бактеріофага ZF-40 (Рис. 3a), а у складі MCTV 3 ізолятів P. carotovorum Б3, Б4, Б12, Б13, Б15 виявлені серологічно споріднені, але неідентичні білкові компоненти з білками бактеріофага ZF-40. Про це свідчить наявність «шпори» між смугами преципітації антигенів з антитілами (рис. 3б). (По центру рис. 3 а і б нанесена сироватка до бактеріофага ZF-40).

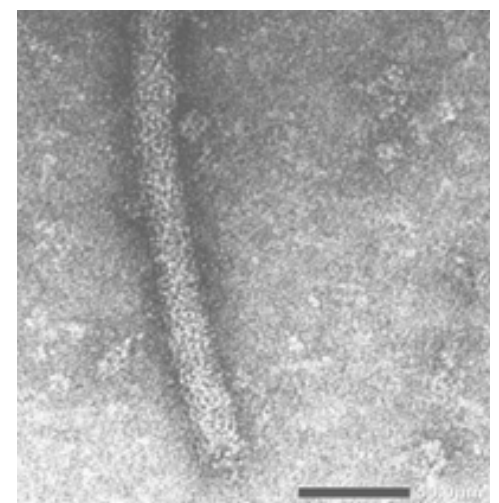

а) нескорочений хвостовий відросток ізоляту Б1

a) non-contractile tail-like particle of isolate B1

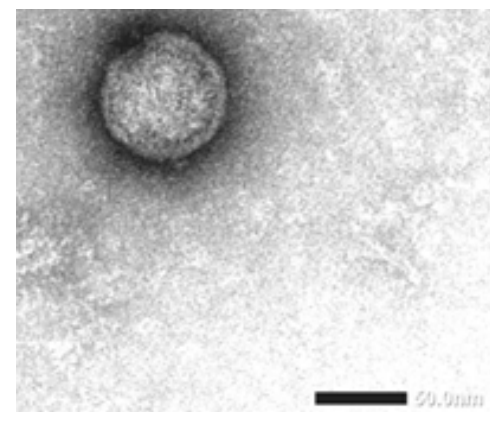

c) сферична частка 3 ізоляту Б2

c) spherical particle of isolate B2

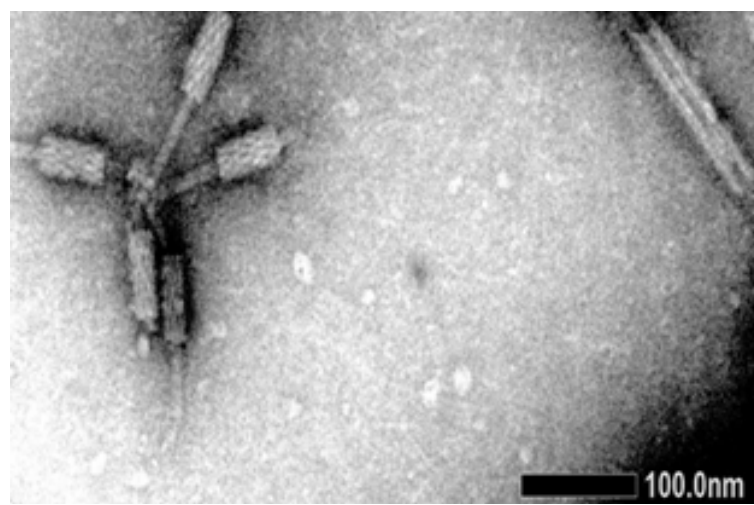

б) скорочені хвостові відростки виділені з ізоляту Б4

b) contractile tail-like particle, obtained from isolate B4

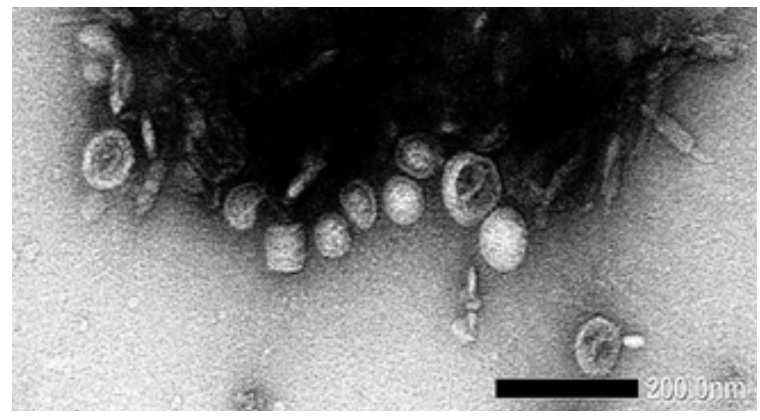

д) суміш бактеріоцинів 3 ізоляту Б16

d) composition of bacteriocins from isolate B16

Рис. 1. Електронномікроскопічне дослідження MCTV з ізолятів P. carotovorum, виділених в різних областях України

Fig. 1. Transmission electron microscopy of MCTV`s $P$. carotovorum isolated from different regions of Ukraine 


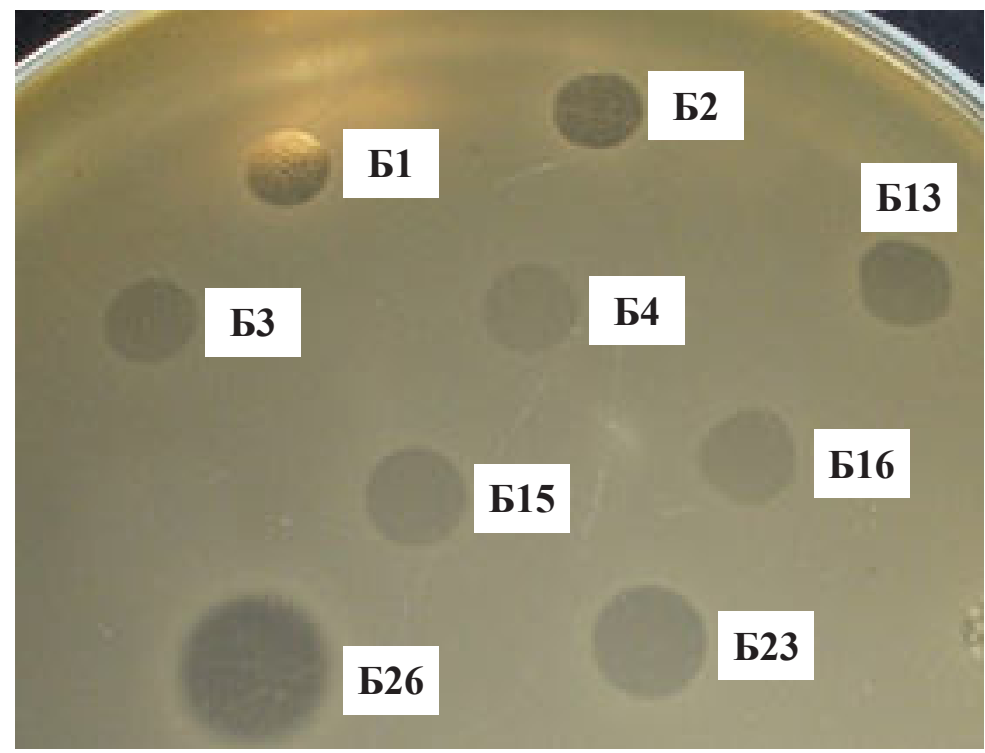

Рис. 2. Кілерна активність МСТV, виділених з ізолятів $P$. carotovorum різних областей України відносно штаму Рcc RC 5297

Fig. 2. The killer activity against to strain Pcc RC 5297 of MCTV P. carotovum strains isolated from different regions of Ukraine



a

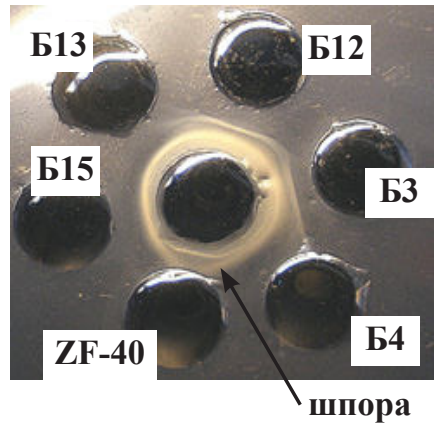

б

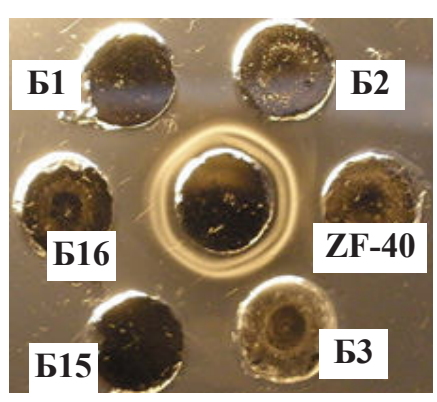

c

Рис. 3. Реакція імунопреципітації в $1 \%$ агарозному гелі Примітка:

а) серологічно споріднені та ідентичні білки з білками бактеріофага ZF-40 ;

б) «шпора» між смугами преципітації антигенів з антитілами ;

с) серологічно споріднені і ідентичні білкові компоненти .

Fig. 3. Thereaction of immunoprecipitation in $1 \%$ agarose gel Note :

a) serologically identity and identical proteins with proteins of ZF-40 bacteriophage

b) "Spur" between the bands of antigen precipitation with antibodies

c) serologically identityand identical proteins components 
За допомогою антисироватки, одержаної до MCTV, виділених з колекційного штаму P. carotovorum J2 у складі бактеріоцинів, одержаних з «українських» ізолятів, а також у складі бактеріофага ZF-40 методом подвійної імунодифузії в агарозному гелі виявлені серологічно споріднені і ідентичні білкові компоненти (Рис. 3c ).

При використанні антисироватки, одержаної до структурних білків бактеріофага ZF40 методом імуноблотинга виявлені серологічно споріднені білки у складі суміші MCTV і бактеріофага ZF40 з молекулярними масами 72, 66, 39 і 24кД (Рис. 4 а ).

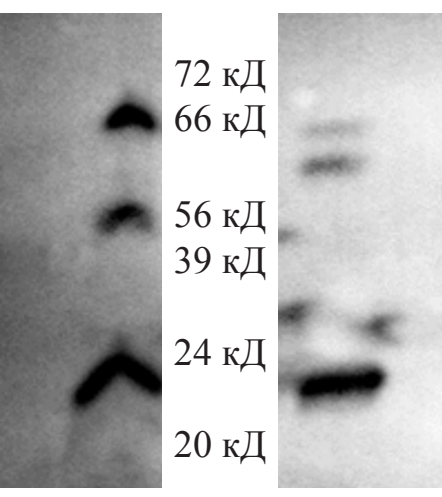

а) антисироватка до бактеріофага ZF40

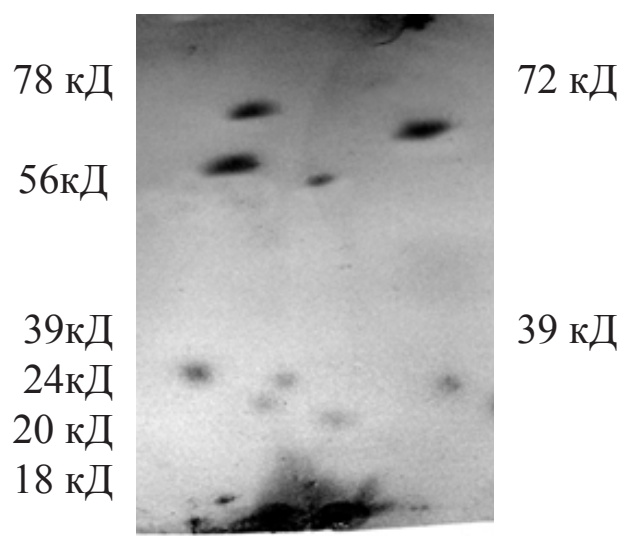

б) антисироватка до MCTV/J2

Рис. 4. Серологічно споріднені білки бактеріоцинів типу фагових хвостових відростків $P$. carotovorum i бактеріофага ZF 40, визначених методом імуноблоту: a) -3 використанням сироватки, одержаної до білкових компонентів бактеріофага ZF40; б) - з використанням сироватки, одержаної до MCTV/J2;

Fig. 4. Serologically related proteins MCTV and bacteriophage ZF40 detected by immunoblotting method:

a) - using the serum obtained for the protein components of the bacteriophage ZF40; b) - using serum obtained from MCTV/J2;

Методом імуноблотингу з використанням антисироватки, одержаної до MCTV/J2, виявлені серологічно споріднені білки з молекулярними масами 78, 56, 39, 20 і 18 кД у бактеріоцинів та 72 і 39 кД у бактеріофага ZF-40 (Рис. 4б)

Відомо, що у бактеріофага ZF40, а також у MCTV основні структурні білки хвостових відростків мають відповідно значення молекулярних мас: білок футляра - 71, 40, 31, 50 кД, внутрішній білок стрижня - 19-20 кД і білки фібрил - 56, 72, 76, 78 кД у бактеріофагів [4] і 68, 72 ,78 кД у бактеріоцинів [8]. Скоріш за все, білки фібрил визначають специфічність адсорбції каротоворицинів $[8,14]$. Загальними, виявленими нами, методом імуноблоту білками фібрил для досліджуваних часток MCTV і ZF40 являються білки 3 молекулярними масами близько 66 і 72 кД.

Обробка зразків MCTV антисироваткою, одержаною до бактеріофагу ZF40, призводить до агрегації часток бактеріоцинів (Рис. 5a). 


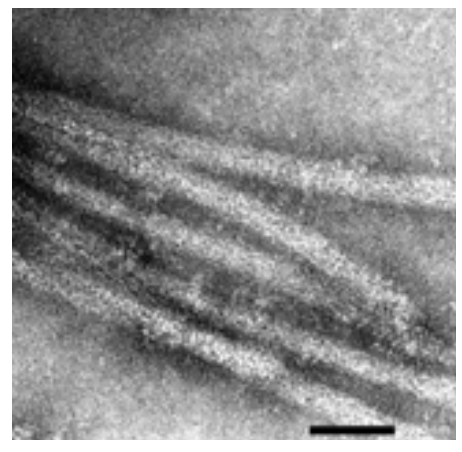

Агрегат хвостових відростків PсcJ2

a

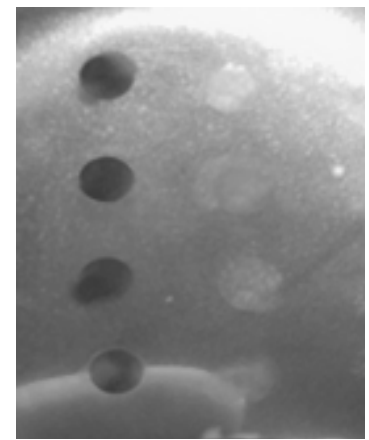

$1 \quad$ II

Pcc RC5297

б

Рис. 5. а) - Агрегат МСTV; б) - Кілерна активність бактеріоцинів до обробки їх антисироваткою (I) і після обробки антисироваткою одержаною до бактеріофага ZF-40 (II) відносно P. carotovorum RC5297

Fig. 5. a) - Agregates of MCTV ; b) - The killer activity of MCTV before (1) and after (II) treatment with antiserum obtained for bacteriophage $\mathrm{ZF40}$ regarding $P$. carotovorum RC5297

Причину утворення агрегату ми поки що достовірно пояснити не можемо. Можливо, наявні в MCTV білкові компоненти, споріднені таким у складі бактеріофага ZF40, зв'язуються з антитілами, одержаними до білків бактеріофага. Можлива наявність і інших причин появи таких агрегатів. Ця агрегація часток призводить до втрати кілерних властивостей MCTV. Бактеріоцини, виділені з бактерій Pcc153(США), Pcc 2М (Росія), Pcc 62 А (Білорусь) втрачали кілерну активність відносно чутливого штаму Рcc RC5297 після обробки їх антисироваткою до ZF40 (Рис. 5 б)).

Лізувальна активність бактеріофага ZF40, обробленого антисироваткою, одержаною до MCTV/J2, також суттєво знижувалася [3].

Таким чином, в результаті проведенних досліджень, у складі MCTV, виділених з Pectobacterium carotovorum різних областей і бактеріофага ZF40 за допомогою антисироваток, одержаних до MCTV/J2, і до бактеріофага ZF40, знайдені серологічно споріднені білкові компоненти. За молекулярною масою (66 кД і 72 кД) вони належать до складу фібрил. Ці компоненти можуть бути факторами впізнавання спільних рецепторів на бактеріальній клітині.

Попередньо ми досліджували виживання клітин Pcc RC 5297 при змішаній інфекції [2]. Критерієм слугували бактеріальні клітини, що вижили після інкубації з фагом, бактеріоцином, а також суміші ZF40 і MCTV/J2 відповідно. При цьому спостерігали збільшення летальної дози при адсорбції суміші фага і каротоворицина в 4 рази порівняно з адсорбцією тільки фагом і в 2 рази порівняно з MCTV/J2. Можливо, такі низькі показники кількості клітин індикаторного штаму, що вижили при сумісному зараженні фагом і бактеріоцином також вказують на спільні рецептори на клітинній оболонці бактерії. 
Для доведення наявності конкуренції за рецептори при сумісному зараженні, проведено підрахунок кількості неадсорбованного фага при адсорбції його на нативних клітинах бактерій. В результаті проведених експериментів було показано факт сумісності рецепторів штаму Pcc RC 5297 для бактеріофага ZF40 і MCTV/J2 [2].

В результаті досліджень виявилося, що у випадку сумісного зараження клітин фагом ZF40 і бактеріоцином J2, кількість неадсорбованого фага в 2 рази перевищує кількість фагових часток при моноінфекції. Таким чином, адсорбційна здатність фага ZF40 і MCTV/ J2 корелює з наявністю серологічно споріднених білків у складі їх часток.

Отже, результати представлених досліджень показують, що ізоляти P. carotovorum з різних регіонів України під дією налідиксової кислоти виділяють велику множину дефектних часток, які, імовірно, представляють собою продукти збірки дефектних помірних фагів при SOS-індукції лізогенних клітин. Pectobacterium carotovorum subsp. carotovorum . Б1, Б3, Б4, Б11, Б12, Б13, Б15, Б16, Б17, Б23, Б26 крім хвостових відростків різної довжини, продукують і сферичні частки, що нагадують фагові головки різного діаметру. При цьому фагоподібні частки відрізняються не тільки за лінійними розмірами, але й за морфолого-структурною організацією.

Виявлені серологічно споріднені білки у складі MCTV ізолятів природних штамів P. carotovorum та бактеріофага ZF-40 свідчить про фагову природу виділених кілерних часток. Крім того серологічно споріднені компоненти у складі MCTV і бактеріофага ZF40 можуть бути факторами впізнавання спільних рецепторів бактеріальною клітиною, бо існує конкуренція при адсорбції на індикаторному штамі Pcc Rc 5297 в умовах змішаної інфекції фага ZF40 i $\mathrm{MCTV} / J 2$.

\title{
Л.А. Максименко
}

\author{
Институт микробиологии и вирусологии им. Д.К. Заболотного НАН Украины, \\ ул. Академика Заболотного, 154, Киев, 03143, Украина, \\ тел.:+38(044)526 94 24, e-mail: maksymenko.l.a@gmail.com
}

\section{МОРФОЛОГО-СТРУКТУРНЫЕ, КИЛЛЕРНЫЕ И СЕРОЛОГИЧЕСКИЕ СВОЙСТВА МАКРОМОЛЕКУЛЯРНЫХ БАКТЕРИОЦИНОВ PECTOBACTERIUM CAROTOVORUM SUBSP. CAROTOVORUМ И ИХ РОДСТВО С БАКТЕРИОФАГОМ ZF 40}

\begin{abstract}
Реферат
Цель. Определение родства между белковыми компонентами макромолекулярных бактериоцинов (MCTV), выделенных из разных природных изолятов Pectobacterium carotovorum subsp. carotovorum и бактериофага ZF 40. Методы. Бактериоцины P. саготоvогт получали индукцией налидиксовой кислотой. Смесь каротоворицинов разделяли ультрацентрифугированием. Электронномикроскопические исследования бактериоцинов проводили
\end{abstract}


при помощи микроскопа JEOL 1400. Бактериофаг ZF 40 выделяли методом слитного лизиса. Киллерную активность МСTV и бактериофага ZF 40 изучали с помощью популяционных диссоциантов бактерий RC 5297 и RC 5195. Серологическое родство белковых компонентов МCTV и бактериофага ZF 40 определяли с помощьью полученных к указанным структурам соответствующчих кроличьих антисывороток. Результаты. Фитопатогенные бактерии P. carotovoruт в результате индукции налидиксовой кислотой, продуцииуют множество макромолекулярных бактериоцинов. Они проявляют антимикробное действие относительно разных штаммов бактерий Р. carotovoruт u Esherichia coli. Электронномикроскопические исследования очищенных фракиий МСТV изолятов Р. сагоtovoruт из разных областей Украины (Б1Б26) показали, что они имеют вид хвостовых отростков бактериофагов, а также сферических частии разного диаметра. Белковый состав МСTV разных изолятов Р. саготоvогит могут отличаться минорными фракциями пептидов. С помощью кроличьей антисыворотки, полученной к MCTV J2, выявлены серологически родственные белки в составе бактериофага ZF 40. Методом иммуноблотинга с использованием антисыворотки, полученной к структурным белкам бактериофага ZF 40, выявлены серологически родственные белки в составе MCTV J2 и бактериофага ZF 40 с молекулярными массами 72, 66, 39 и 24 кДа. Обработка смеси МСТV кроличьей антисывороткой к бактериофагу ZF 40 , приводит к утрате их киллерной активности. Выводы. МСТV, полученные из лизатов новых изолятов бактерий P. carotovorum, выделенных в Украине представляют собой большое множество, отличаются по размерам и имеют разные морфолого-структурные показатели. Они имеют в своем составе серологически родственные белки с белковыми компонентами бактериофага ZF40. Полученные факты свидетельствуют о фаговой природе макромолекулярных бактериоцинов.

Ключевые слова: Pectobacterium carotovorum subsp. carotovorum, макромолекулярные бактериоцины, бактериофаг ZF 40, белки, серологическое родство

\title{
L.O. Maksymenko \\ Zabolotny Institute of Microbiology and Virology NAS of Ukraine, 154, Zabolotny str., Kyiv,03143, Ukraine, tel.: +38(044)526 94 24; e-mail: maksymenko.1.a@gmail.com \\ MORPHO-STRUCTURAL, KILLER AND SEROLOGICAL PROPERTIES OF MACROMOLECULAR BACTERIOCINS OF PECTOBACTERIUM CAROTOVORUM SUBSP. CAROTOVORUM AND THEIR RELATEDNESS TO BACTERIOPHAGE ZF40
}

\begin{abstract}
Summary
The aim was to examine the relationship between the protein components of macromolecular bacteriocins (MCTV) obtained from different natural isolates of Pectobacterium carotovorum and bacteriophage ZF40. Methods. Bacteriocin production was obtained by nalidixic acid. The bacteriocin samples were separated
\end{abstract}


by ultracentrifugation. Transmission electron microscopy of bacteriocins was performed using JEOL 1400. Phage ZF40 was obtained by confluent lysis. MCTV and phage killer activity were tested against RC5297 and RC5195 population dissociants. The serological relatedness of MCTV and phage ZF40 was examined using specific rabbit antisera. Results. The phytopathogenic bacteria P. carotovorum produce a variety of macromolecular bacteriocins under nalidixic acid induction. They show antimicrobial activity against different strains of P. carotovorum and Esherichia coli. Electron microscopy analysis of purified MCTV fractions of the P. carotovorum strains isolated in different part of Ukraine has shown that they have the appearance of bacteriophage tails and spherical particles of different diameters. The protein composition of MCTV from the various P. carotovorum isolates differ by minor peptide fractions. Using rabbit antiserum, serologically related proteins were detected in phage ZF40 and MCTV J2. Immunoblotting analysis with rabbit antiserum against the ZF40 structural proteins has revealed serologically related proteins of 72.66, 39 and $24 \mathrm{kDa}$ in the structure of MCTV J2 and phage ZF40. Applying by rabbit antiserum against phage ZF40 resulted in the loss of MCTV killer activity. Conclusions. MCTVs obtained from lysates of new isolates of $P$. carotovorum, isolated in Ukraine, differ in size and have different morphological and structural parameters. They consist of proteins serologically related to the ZF40 structural proteins. Obtained data confirmed bacteriophage nature of macromolecular bacteriocins.

Key words: Pectobacterium carotovorum subsp. carotovorum, macromolecular bacteriocins, bacteriophage ZF40, proteins, serological relationships.

\section{СПИСОК ВИКОРИСТАНОЇ ЛІТЕРАТУРИ}

1. Максименко Л.А., Пархоменко Н.И., Мороз С.Н., Горб Т.Е. Изучение свойств изолятов пектолитических фитопатогенных бактерий, выделенных в Украине// Мікроб.журн. - 2013. - 75. №6. - С. 66-72.

2. Максименко Л.А., Романюк Л.В. Связь серологического родства белков с адсорбцией частиц бактериоцина Pectobacterium carotovorum J2 и бактериофага ZF-40.// Доповіді НАН України. 2016. №12. - С. 90-94.

3. Максименко Л.А., Товкач Ф.И. Серологическое родство бактериоцинов Erwinia carotovora,выделенных из различных экологических ниш, со структурными белками бактериофага ZF-40. // Доповіді НАНУ.2012. 7: $158-163$.

4. Панщуина А.И., Товкач Ф.И., РоманюкЛ.В., Максименко Л.А. Физико-химические свойства умеренного бактериофага ZF-40 Erwinia carotovora// Мікроб.журн.,2007. - Т. 69, № 2. - С. 15-22.

5. Товкач Ф.И. Биологические свойства и классификация бактериоцинов Erwinia carotovora// Микробиология. - 1998. - 67, № 6. - С. 767-774.

6. Товкач Ф.И. Дефектная лизогения Erwinia carotovora// Микробиология. -2002. - 71, № 3. - 359-367.

7. Товкач Ф.И. Структурная организация частиц и рестрикционный анализ ДНК умеренного бактериофана ZF-40 Erwinia carotovora// Микробиология. - 2002. - 71, № 1. - С. 75-81.

8. Товкач Ф.И., Максименко Л.А. Полипептидный состав и киллерная специфичность как показатели множественности каротоворицинов //Miкробіол.журн. - 2010. -72. № 5. - С. 41-48. 
9. Comeau A. M., Tremblay D., Moineau S., Rattei T., Kushkina A.I., Tovkach F.I., Krisch H.M., Ackermann H.W. Phage morphology recapitulates phylogeny: The comparative genomics of a new group of myoviruses// PLoS ONE. July 2012. - 7. $-\mathrm{N}$ 7. -40102 .

10. Daw M.A. Bacteriocins: nature, function and structure//M.A.Daw, F.R.Falkiner// Micron. - 1996. - V. 27, № 6. - P. 461-479.

11. Laemmli U.K. Cleavage of structural proteins during the assembly of the head of bacteriophage T // Nature. - 1970. - 227. № 5259. -P. 680-685.

12. Maeda A., Nomura M. Interaction of colicins with bacterial cells. I. Studies with radioactive colicins// J. Bacteriol. - 1966. - 91, № 2. - P. 685-694.

13. Nakayama K., Takashima K., Ishihara H. et al. The R-type pyocin of Pseudomonas aeruginosa is related to $\mathrm{P} 2$ phage, and the F-type is related to lambda phage //Mol.Microbiol. - 2000. - 38, N 2. - P. 213-231.

14. Nguyen H.A., Tomita T.T., Hirota M., Sato T., Kamio Y. A simple purification method and morphology and component analyses for carotovoricin Er, a phage- Erwinia carotovora Er// Bioshi.Biotechnol.Biochem. 1999. - 63,N8. - P. 1360-1369.

15. Ouchterlony $O$. Antigen-antibody reactions in gels. In Hadbook immunodiffusion and Immunodiffusion and Immunoelectrophoresis// Ann. Arbor.Michigan.Ann.Arbor.Science Publishers. - 1968. - P. 37.

16. Towbin H., Stalhelin T., Gordon J. Electrophoretic transfer of proteins from polyacrylamide gels to nitrocellulose sheets: procedure and applications// Proc.Nat.Acad.Sci. USA. - 1979. - 76.N9. - P. 4350-4354.

\section{References}

1. Maksymenko LA, Parkhomenko N I, Moroz SN, Gorb TE. Properties Investigation of isolates of pectolitic phytopathogenic bacteria obtained in Ukraine. Microbiol.j.2013;75(6):66-72. (In Russian)

2. Maksymenko LA, Romaniuk LV. The relation between the serological similarity of proteins and the adsorption of particles of Pectobacterium carotovorum J2 bacteriocins and bacteriophage ZF40. Dopov. NANU.2016; 12: 90-95 (In Russian).

3. Maksymenko LA, Tovkach FI. Serological relationship of bacteriocins' proteins of Erwinia carotovora isolated from various ecological regions and with structural proteins of bacteriophage ZF40. Dopov.NANU. 2012;7:158163. (In Russian)

4. Panshchina AI, Tovkach FI, Romaniuk LV, Maksymenko LA. Physico-chemical properties of temperate bacteriophage ZF40 of Erwinia carotovora .Microbiol. J.2007;69(2):15-22. (In Russian)

5. Tovkach FI. Biological properties and classification of Erwinia carotovora bacteriocins. Microbiology.1988; 67(6): 767-774. (In Russian)

6. Tovkach FI. Defective lisogeny in Erwinia carotovora. Microbiology. 2002; 71(3): 359-367. (In Russian)

7. Tovkach FI. Temperate bacteriophage ZF40 of Erwinia carotovora: Phage particle structure and DNA restriction analysis. Microbiology. 2002; 71(1): 75-81. (In Russian) 
8. Tovkach FI, Maksymenko LA. Polypeptide composition and killer specificity as indices of multiplicity of carotovoricins. Microbiol.J.2010; 72(5) :41-48 (In Russian).

9. Comeau AM, Tremblay D, Moineau S, Rattei T, Kushkina AI, Tovkach FI, Krisch HM, Ackermann HW. Phage morphology recapitulates phylogeny: The comparative genomics of a new group of myoviruses. PLoS ONE. 2012; 7(7): 40102.

10. Daw MA. Bacteriocins: nature, function and structure.Micron. 1996; 27(6): 461-479.

11. Laemmli UK. Cleavage of structural proteins during the assembly of the head of bacteriophage T . Nature. 1970;227(5259): 680-685.

12. Maeda A, Nomura M. Interaction of colicins with bacterial cells. I. Studies with radioactive colicins. J. Bacteriol. 1966; 91, №2 :685-694.

13. Nakayama K, Takashima K, Ishihara H. et al. The R-type pyocin of Pseudomonas aeruginosa is related to $\mathrm{P} 2$ phage, and the F-type is related to lambda phage . Mol.Microbiol. 2000; 38, №2 :213-231.

14. Nguyen HA,Tomita TT,Hirota M,Sato T,Kamio Y. A simple purification method and morphology and component analyses for carotovoricin Er, a phageErwinia carotovora Er. Bioshi.Biotechnol.Biochem. 1999; 63,N8:13601369.

15. Ouchterlony O. Antigen-antibody reactions in gels . In Hadbook immunodiffusion and Immunodiffusion and Immunoelectrophoresis. Ann.Arbor. Michigan.Ann.Arbor.Science Publishers. 1968 :37.

16. Towbin H, Stalhelin T, Gordon J. Electrophoretic transfer of proteins from polyacrylamide gels to nitrocellulose sheets: procedure and applications. Proc.Nat.Acad.Sci. USA. 1979;76(9):4350-4354.

Стаття надійшла до редакції 28.05.2020 р. 